\title{
Why Not Heritage Speakers?
}

\section{Citation}

Montrul, Silvina, and Maria Polinsky. 2011. Why not heritage speakers? Linguistic Approaches to Bilingualism 1(1).

\section{Published Version}

http://www.benjamins.com/cgi-bin/welcome.cgi

\section{Permanent link}

http://nrs.harvard.edu/urn-3:HUL.InstRepos:4726010

\section{Terms of Use}

This article was downloaded from Harvard University's DASH repository, and is made available under the terms and conditions applicable to Open Access Policy Articles, as set forth at http:// nrs.harvard.edu/urn-3:HUL.InstRepos:dash.current.terms-of-use\#OAP

\section{Share Your Story}

The Harvard community has made this article openly available.

Please share how this access benefits you. Submit a story.

\section{Accessibility}




\title{
Why not heritage speakers?
}

\author{
Silvina Montrul and Maria Polinsky \\ University of Illinois at Urbana-Champaign and Harvard University
}

In her keynote article, Sorace offers an update on the status of the Interface Hypothesis (IH). Sorace summarizes the $\mathrm{IH}$ in the opening paragraph by stating that it was proposed

"as an attempt to account for patterns of non-convergence and residual optionality found at very advanced stages of adult second (L2) acquisition. The IH originally proposed that language structures involving an interface between syntax and other cognitive domains are less likely to be acquired completely than structures that do not involve this interface. At the same time, the IH was extended to bilingual first language (L1) acquisition and to the very early stages of L1 attrition, which exhibit optionality in precisely the same structures: this provides a unifying framework for the study of bilingual language development.” (pp. XX)

Sorace suggests that there have been misconceptions of the IH in recent work by other researchers, as well as "unwarranted extensions of the IH to domains other than the ones for which is was proposed" (p. XX). Two of the main misconceptions or "unwarranted extensions" Sorace considers are 1) the representational status of interfaces and 2) the extension of the IH to L2 acquisition in general (not just near-natives) and to cases of what she calls "intergenerational attrition”. Montrul (in press) already questions the representational status of interfaces, while Lardiere's and White's commentaries in this issue question the "why not" extension of the IH to L2 acquisition. In this commentary, we would like to question Sorace's assertion that "intergenerational attrition" is not relevant for the IH. Sorace writes:

"Heritage speakers (who are the focus of most research on L1 attrition) are one stage 
ahead compared to first-generation individual attrited speakers: the input received by second generation speakers is typically different from the input received from their parents and their grammatical representations may also be affected by attrition, in addition to their integration abilities in processing. Heritage speakers may acquire a divergent grammar, if the input is only qualitatively different, or an incomplete grammar, if the input is also quantitatively impoverished (Sorace 2005). ${ }^{.1}$

Heritage speakers are typically second-generation immigrants whose home language is a minority language and who are more fluent in the dominant language of their society (Valdés 2000; Polinsky \& Kagan 2007). We agree with Sorace that heritage speakers may represent a more advanced stage of attrition. However, significant attrition often targets those phenomena that are already at risk in the initial stage of the language (Sasse 1992; Polinsky 2006, McWhorter 2007, a.o.). So if the IH uses as its database the changes that are found in near-native speakers, it is not unreasonable to think that the same changes will take place in the "stage

${ }^{1}$ Studies of heritage speakers' input are needed in order to understand what these speakers are really exposed to on a daily basis. The sociolinguistic data indicate that, in general, heritage speakers only speak the language with their parents or with "full speakers " of the language; they rarely use the language among themselves as they do with English (Carreira \& Kagan in press). In fact, an issue of qualitatively different input is documented in Paradis \& Navarro's (2003) study of the Spanish-English simultaneous bilingual child Manuela with respect to parental patterns of use of null and overt subject pronouns in Spanish, a study that Sorace in the target paper considers within the purview of the IH. Manuela is, in fact, a heritage speaker of Spanish, if only very young. Many of the heritage speakers we have studied as adults were like Manuela. 
ahead", i.e., heritage speakers. After all, near-native speakers, who include first generation émigrés living outside their L1 domain, are the ones that provide input to heritage speakers.

In fact, several studies have shown that that null/overt subjects, the phenomenon on which the IH has mainly focused, are also highly affected in heritage language speakers of Spanish (Montrul 2004, 2006) and other languages (Polinsky 1997) in ways that are consistent with the IH. Actually, Silva-Corvalán (1994) was among the first to notice this phenomenon with Spanish heritage speakers and L1 attriters, before the IH was proposed, and this work is not typically acknowledged by Sorace and colleagues in discussions of the IH. Heritage languages whose baseline is pro-drop are reported to lose the pro-drop feature or to use it in a more limited manner - for example, Hungarian (de Grot 2005), Hindi (Mahajan 2009), Korean (Choi 2003), Tamil and Kabardian (Polinsky 1997), Polish (Dubisz 1997, 2001; Polinsky 1997; Brehmer \& Czachor 2010), Arabic (Albirnini et al. in press).

Heritage speakers are notorious for having tremendous variance within their populations - from very high proficiency cases where some registers may be affected, to socalled overhearers (Au et al. 2002). Setting aside high-proficiency heritage speakers, we find that the remaining population of heritage speakers manifests both attrition (Montrul 2008, Polinsky 2005, in press) and incomplete acquisition (Montrul 2002, Polinsky 1997). Given the growing evidence for attrition in heritage speakers, it is especially important to compare their attrition to that found in the first-generation speakers who constitute the empirical base of the IH.

Furthermore, many heritage speakers ARE indeed cases of bilingual L1 acquisition, and bilinguals are the population that Sorace claims the IH is about (Sorace et al. 2009). Unlike many of the simultaneous bilingual children studied in the literature on bilingual acquisition who may be "balanced", for most heritage speakers the family language is the weaker language. Sorace 
(2005) claims that the input heritage speakers are exposed to is qualitatively different, without actual empirical evidence, assuming that heritage speakers receive input in the minority language from their parents, whose language may be already attrited, and from other heritage speakers whose language is also different.

We would also like to question the IH's preoccupation with the syntax-discourse interface. Part of this preoccupation stems from historical reasons: our field has had a longstanding interest in reducing cross-linguistic variation to parameters, and the null-subject parameter is one of the best known and most extensively explored parameters (cf. Jaeggli \& Safir, 1989). If Sorace's explanation of the problems with the syntax-discourse interface is on the right track, it behooves us to understand what is so unique about null pronominals that they seem to be the only affected area of an interface. One would naturally want to ask what types of interface phenomena are prone to change under contact. Additionally, is only the conceptual/intentional interface affected by attrition? What about the sensory/motor interface?

We would also like to suggest that the loss of pro-drop may have a simpler, alternative explanation: speakers deviating from the L1 ideal have a more general difficulty in establishing syntactic dependencies, especially when such a dependency links two elements at a distance. A null pronominal is always an element that has to be licensed and identified (Rizzi 1986), thus the licensing and co-indexation with a DP at a distance causes a significant problem in heritage grammars. Difficulties in creating and maintaining a dependency also arise with respect to binding, which accounts for the difficulties observed in the interpretation of anaphors in heritage speakers. The difficulty may vary across heritage languages or across proficiency levels, or both; Kim et al. $(2009,2010)$ show that heritage speakers still retain robust control of the syntactic properties that license local and long distance anaphors in their language. 
In sum, we believe that heritage speakers are not only relevant to the $\mathrm{IH}$, but also an important testing ground for it; the encounter with this population may make the hypothesis both stronger and richer.

\section{References}

Albirini, A., E. Benmamoun, \& E. Saadah. In press. Grammatical features of Egyptian and Palestinian Arabic heritage speakers' oral production. Studies in Second Language Acquisition 45.

Au, T., L. Knightly, S. Jun, \& J. Oh. 2002. Overhearing a language during childhood. Psychological Science 13, 238-243.

Brehmer, B. \& A. Czachor. 2010. A case study of two groups of Polish-German bilinguals. Paper presented at the Workshop on Incomplete Acquisition and Language Attrition. Hamburg University, July 2010.

Carreira, M. \& O. Kagan. In press. The results of the National Heritage Language Survey: Implications for teaching, curriculum design, and professional development. Foreign Language Annals.

Choi, H.-W. 2003. Paradigm leveling in American Korean. Language Research 39, 183-204.

de Groot, C. 2005. The grammars of Hungarian outside Hungary from a linguistic-typological perspective. In A. Fenyvesi (ed.). Hungarian language contact outside Hungary, 351370. Amsterdam: John Benjamins.

Dubisz, S. 1997. Język polski poza granicami kraju—proba charakteristiki kontrastowej. In S. Dubisz (ed.). Jẹzyk polski poza granicami kraju, 324-376. Opole: Uniwersytet Opolski. 
Dubisz, S. 2001. Język polski poza granicami kraju. In S. Gajda (ed.). Język polski, 492-514. Opole: Uniwersytet Opolski.

Jaeggli, O. \& K. Safir (eds.). 1989. The Null Subject parameter. Dordrecht: Kluwer.

Kim, J-H, Montrul, S. \& J. Yoon. 2009. Binding interpretation of anaphors in Korean heritage speakers. Language Acquisition 16, 3-35.

Kim, J-H., Montrul, S. \& J. Yoon. 2010. Dominant language influence in acquisition and attrition of binding: Interpretation of the Korean reflexive caki. Bilingualism: Language and Cognition 13, 73-84.

Mahajan, G. 2009. Heritage-Schmeritage: It's their language. Paper presented at the Second Language Acquisition Conference, San Diego, April 2009.

McWhorter, J. 2007. Language interrupted. Signs of non-native acquisition in standard language grammars. Oxford: Oxford University Press.

Montrul, S. 2002. Incomplete acquisition and attrition of Spanish tense/aspect distinctions in adult bilinguals. Bilingualism: Language and Cognition 5, 39-68.

Montrul, S. 2004. Subject and object expression in Spanish heritage speakers. A case of morphosyntactic convergence. Bilingualism: Language and Cognition 7, 125-142.

Montrul, S. 2006. On the bilingual competence of Spanish heritage speakers. Syntax, lexicalsemantics and processing. International Journal of Bilingualism 10, 37-69.

Montrul, S. 2008. Incomplete acquisition in bilingualism. Re-examining the age factor. Amsterdam: John Benjamins.

Montrul, S. In press. Interfaces and incomplete acquisition. Lingua, Special issue on Interfaces in language acquisition . 
Paradis, J. \& S. Navarro. 2003. The use of subjects by a Spanish-English bilingual child: crosslinguistic influence or the influence of the input? The Journal of Child Language 30, 371-393.

Polinsky, M. 1997. Cross-linguistic parallels in first language loss. Southwest Journal of Linguistics 14, 87-123.

Polinsky, M. 2005. Word class distinctions in an incomplete grammar. In D. Ravid \& H. BatZeev Shyldkrodt (eds.). Perspectives on language and language development, 419-436. Dordrecht: Kluwer.

Polinsky, M. 2006. Incomplete acquisition: American Russian. Journal of Slavic Linguistics 14, 191-262.

Polinsky, M. In press. Reanalysis in adult heritage language: A case for attrition. Studies in Second Language Acquisition.

Polinsky, M, \& O. Kagan. 2007. Heritage languages: In the 'wild' and in the classroom. Language and Linguistics Compass. 1(5), 368-395.

Rizzi, L. 1986. Null objects in Italian and the theory of pro. Linguistic Inquiry 17, 501-557.

Sasse, H.-J. 1992. Theory of language death. In M. Brenzinger (ed.) Language death: Factual and theoretical explorations with special reference to East Africa, 7-30. Berlin: Mouton de Gruyter.

Silva-Corvalán, C. 1994. Language contact and change: Spanish in Los Angeles. Oxford: Oxford University Press.

Sorace, A. 2005. Syntactic optionality at interfaces. In L. Cornips \& K. Corrigan (eds). Syntax and Variation: Reconciling the Biological and the Social, 46-111. Amsterdam: John Benjamins. 
Sorace, A. \& L. Serratrice. 2009. Internal and external interfaces in bilingual language development: Beyond structural overlap. International Journal of Bilingualism 13, 195210.

Valdés, G. 2000. Introduction. Spanish for Native Speakers, Volume I. AATSP Professional Development Series Handbook for teachers K-16. New York, NY: Harcourt College. 